\title{
The South African Universities Post - Merger Mess: Problems and Challenges of Transformation
}

\author{
Anis Mahomed Karodia (PhD) \\ Professor, Senior Academic and Researcher, Regent Business School, Durban, Republic of South Africa \\ akarodia@regent.ac.za
}

\author{
Ahmed Shaikh \\ Managing Director and Academic, Regent Business School, Durban, Republic of South Africa \\ Dhiru Soni (D.Phil)
}

Director of Research, Regent Business School, Durban, Republic of South Africa

Doi:10.5901/mjss.2015.v6n3s1p326

Abstract

The paper attempts to address the rather complex and many issues raised in the title of the paper. This is important on the basis that an evaluation of these fundamental issues after twenty years of South African democracy is important to the people of South Africa. In attempting to do this, the paper does not pretend to capture the salient and subtle nuances that straddle the issues raised in the title of the paper because higher education in South Africa, is in a state of flux and has not really delivered to the needs and real development of the country post democracy in 1994. In this regard issues concerning transformation, Africanization of the curriculum for higher education, enlightened leadership, and do neoliberal policies destroy human potential for the emergence of education in a democratic South are discussed, in order to deal with the post - merger mess. The issues raised in this paper must therefore be given serious attention by policy makers within higher education and more importantly by government, in order to realize the goals of higher education through a sustained and inclusive transformation strategy. The starting point is to project on the post 1994 merger mess of universities in South Africa, using the example of the newly constructed and amalgamated university of KwaZulu - Natal. This example can be extrapolated to project on the merger mess throughout all universities in the country that were affected by an ill - conceived plan by the democratic government post 1994. A host of issues pertinent to this paper in terms of transformation of higher education will be elaborated upon. The importance of all of these issues cannot be underestimated in respect to higher education discourse in South Africa. The abstract therefore, does not discuss the areas captured within the ambit of the title of the paper because, these issues will be raised within the body of the paper, amidst a host of issues including transformation, the Africanization of the South African education curriculum, the necessity of engineering the concept of enlightened leadership, and asks the question, do neoliberal policies in South Africa destroy human potential for the emergence of higher education in the Republic of South Africa. The writers are woefully aware that they raise very sensitive issues and that they will court criticism from education quarters in South Africa but seek solace in the embracing reality that, open debate and criticism is necessary from the perspective of academic freedom and, more importantly to enhance the education discourse.

Keywords: Merger, Transformation, Africanization, Curriculum, Higher Education, Universities, Leadership, Neoliberal Policies, Capitalism, Human Potential, Democracy

\section{Research Methodology}

The research methodology utilized in this paper, does not follow the classical research approach employed in traditional approaches to research. In no way does this alter the thrust and aims of the paper. In reality the paper assumes significance on the basis that it explores a number of important education issues that affect South Africa, post 1994 and after nearly twenty one years of democracy. In this sense the paper is most pertinent and is necessary to understand the issues being raised, in order to usher in and bring about necessary, urgent, sustained and coordinated transformation of the higher education landscape in democratic South Africa. The authors in unpacking these issues will lean heavily upon newspaper articles that appeared in the South African press / media and will also rely upon their own critical analysis and experiences over time, in terms of the subject matter under discussion. In this regard, therefore, content analysis is used 
in a qualitative framework and as such no primary research is undertaken, but rather the use of secondary sources is the primary motivation of the study. In other words the paper undertakes the desktop approach.

\subsection{Objectives Of The Study}

The objectives of the study were as follows:

- To assess the strengths and weaknesses of the post - merger exercise as was envisaged for higher education amalgamation in post apartheid South Africa by the Ministry of higher education and the government post 1994 when freedom and democracy became a reality in South Africa.

- To criticize the post - merger exercise because of the inherent difficulties that higher education confronts in a democratic South Africa.

- To underscore that there were hidden and parochial agenda's that were engineered by interested parties and there was very little political guidance to the merger processes.

- Further to assess the situation by means of a limited literature review and to make some recommendations, for change, with the hope that government will use the recommendations to confront the situation that now permeates higher education in South Africa, with a view of commissioning further and new research in this direction.

\subsection{Literature Review and Theoretical Framework}

The literature review pertaining to this study was limited to newspaper articles, some reports and analysis by the authors where applicable, in order to discuss and frame the theoretical perspectives pertinent to the higher education discourse as concerns the post - merger mess in South Africa. The theoretical framework and discussion in this paper, it is hoped will allow other researchers to undertake in depth studies in this direction, to glean relevant information by following the classical approach of research in terms of gathering primary information by constructing more in depth studies together with enhancing the utilization of secondary sources of information. In addition, such new studies will allow government to appreciate the problems and challenges of the post - merger mess at universities in South Africa and, consider the necessary remedial action that has to be undertaken, in order to rectify the mistakes that now confront higher education in the country.

\subsection{Findings, Conclusions and Recommendations}

There will be no finite findings that will be elaborated upon because the findings will be discussed and dispersed throughout the paper. It is not the intention of the paper to limit itself to findings in the classical sense, but rather to project on critical analytical discussion and debate. It is hoped that the discussion therefore, will pave the way for some discussion within the higher education sector of the country. Further that the paper and, its innate discussions and findings will stimulate further interest and discussion within higher education circles and stimulate reasoned and rational criticism of aspects of this paper. However, the writers of this paper make some salient findings, conclusions and recommendations at the end of the paper and place on record that these conclusions and recommendations are not all inclusive.

\subsection{Creativity Value}

The creativity value is punctuated on the basis of opening up and stimulating reasoned debate among education faculties of both public and private universities and college institutions; particularly the Ministry of Higher Education and within the large government bureaucracy, who in many ways, post 1994 have lived in a state of denial, as concerns the serious challenges and manifest problems that have and still confront and impact upon higher education in South Africa (Soni, Karodia, and Dwakinun, 2013:36; Karodia, Soni and Rahman, (2013: 22 - 33). The creativity value of the paper is underscored by the importance of the issues being raised. This importance becomes pertinent to a country that is in a state of transformation in most sectors of the economy because of the apartheid ideology of the past (Vally and Motala, 2014; Hay, Karodia, Bayat, and Soni, 2013: 14 -21). The paper assumes significance not only to the economy of South Africa but, to the general development of the country and to this end higher education, which is required to play a pivotal role in transformation discourse of the reconstruction of the country. 


\section{Introduction}

The paper brings to the fore the sorry aspects of the post - merger mess because, it is an indication of a sorry state of affairs post 1994 and that, many will argue that corporatization is a natural and inevitable consequence of universities becoming too large in South Africa, in order to deal with real transformation issues. (The reader is urged to consult the work of Nithaya Chetty and Christopher Merrett "The Struggle for the Soul of a South African University: The University of KwaZulu Natal - Academic Freedom, Corporatization and Transformation) (Kindly note that positive narratives of the mergers of South African Universities are only provided by the government and it's Ministry of Higher Education. It is therefore, not necessary to quote them because the paper looks at the pitfalls in the merger exercise. Readers are urged to consult the Ministry of Higher Education website in this regard). Ten years after the university's merger, it has been determined by academics that both internal and external politics have caused massive damage at the KwaZulu Natal university and therefore, the time has come to end academia's ivory trade and, therefore, universities must shift their focus and explore better ways of fostering a more democratic South African society. On the other hand more than ten years after the University of KwaZulu Natal University merger, it can be argued that both internal and external politics have caused massive damage to higher education. Issues that relate to the untangling of the merger mess, the history of mergers and a critical review of the higher education mergers in South Africa as enunciated by the South Africa Students Congress in 2009, at its $16^{\text {th }}$ National Congress - Beyond the Big Bang Mergers will be discussed to situate the subject matter accordingly.

Arguably, quality in South African universities has been compromised for a very long time (Edward Weber Ed. 2008 - A Series of Articles on Local Realities, Practices and Reforms: Educational Change in South Africa). The situation has not really improved since the dawn of democracy in 1994 because, there was an over zealousness by the democratic government to engineer change for the sake of change and a number of salient and most important transformation issues were not really intellectually thought about in spite a plethora of sound advice, papers, well-constructed policies on education transformation and within the ambit of policy imperatives that were engineered by education think tanks. As a downside both government and many of the traditional and historic apartheid White universities claim that they are all working to change the racial demographics of their academic staff. There is very little evidence of this after two decades of South African democracy particularly within the former apartheid White universities. We still find racial apartheid demographics within the landscape of many South African universities. Given all of this it is imperative that employers, and colleges must join forces because it is essential on the basis of a lack of management skills in South Africa that, if the government does not intervene decisively the needs of the country and of students must match those of business and automatically translate into matching the needs and requirements of the failing economy (Mail and Guardian, 2015 - See Bibliography for various articles, and Karodia, 2014). On the other hand and, in terms of dealing with engineering quality higher education, it is necessary and imperative to intervene at the basic education level first, in order to set the trajectory for quality higher education. We thus find in South Africa that some public schools pay for teachers with monies meant to fund other important essential activities (These two issues are not discussed in this narrative, Soni, Karodia and Dawkinun, (2013: 36 - 39) who state that "they are not discussed because it concerns basic and not higher education discourse and, is a trend in South Africa because basic education is drastically underfunded by government since the dawn of democracy in 1994. It is obvious that a political commitment is needed to resolve the teacher shortage in many South African schools, especially in the historically disadvantaged and rural areas of South Africa, which has been overtly compromised and neglected by the democratic government, since the dawn of democracy in 1994 and affects the quality of higher education.

Given the above, it is necessary to understand and appreciate that enlightened leadership is required and urgently needed to secure both transformation and to secure academic freedom. In this regard there are threats and a new book analyzes the threats that confront South African universities and proposes ways of resisting them (The reader must consult the book by John Higgins (Wits University Press): Academic Freedom in a Democratic South Africa: Essays and Interviews on Higher Education and the Humanities). On the other hand many argue that neoliberal policies destroy human potential and devastate the economy in South Africa. In this regard (Readers are urged to consult the new book edited by Salim Vally and Enver Motala - Education, Economy and Society (University of South Africa Press). They argue that there has to be a better world in terms of skills and economic analyses.

Against the background of all of this, the Africanization of the higher education curriculum and that of basic education must after twenty one years of South African democracy become a government priority and, this intervention has become long overdue. It is hoped that the issues raised in the introduction of this paper will meaningfully contribute to the transformation discourse of higher education in South Africa. 


\subsection{The Merger Mess}

Untangling the merger mess is long overdue and must be reexamined in terms of finding possible solutions according to the African National Congress (ANC) Secretary General and, he said that "reversing the mergers was not an option" (Dibetle, 2008: 1). The idea is that it is not a call for universities to demerge but that there should be a review. This is a move in the right direction but since this announcement nothing tangible has occurred in this direction. University mergers were first proposed in 2001 and implemented in 2003 and the exercise in its initial phases have cost the government and the tax payer some R3 billion rand. "The lack of funding and the manner in which mergers were conducted according to Pityana" (in Dibetle, 2008) has exacerbated the problem of the merger of South African universities post 1994. One of the downsides of the merger strategy was that it left most of the so - called traditional apartheid universities intact such as the Universities of Witwatersrand, Pretoria, Stellenbosch, Rhodes, and Cape Town and to a very limited extent the Free State University (only took in the small QuaQua campus of a homeland) This has allowed these universities to remain unscathed and were thus able to maintain the apartheid status quo as opposed to the traditional and historically disadvantaged black universities which included the universities of the Bantustan homelands, such as the University of Bophuthatswana, The University of Zululand, the University of Venda, The University of the North and the University of Fort Hare, and the University of Durban Westville which was incorporated into the University of Natal and now called the University of KwaZulu - Natal.

The University of Limpopo was formed from the former University of Polkwane and the Medical University of Southern Africa (MEDUNSA). This merger has been criticized for lack of compatibility between the two institutions and the huge distance between the campuses. Tshwane University of Technology is South Africa's second - biggest university after the University of South Africa (UNISA is a distance learning institution with an international, regional and local presence). A number of Technikons (vocational institutions offering some degree programmes and diplomas were re - designated as universities. This was a move in the wrong direction and has contributed to the tremendous skill shortages in the country and added more confusion to the reconstruction of higher education in post - apartheid South Africa. The Walter Sisulu University is spread over a very large area, including Mthatha, East London, Butterworth and Queenstown in the Eastern Cape Province. It was formed by the merger of the Eastern Cape Technikon, Border Technikon and the Homeland University of the Transkei. The North West University (NWU) came from the merger of the apartheid Afrikaans Potchefstroom University of Christian Higher Education and the Homeland University of Bophuthatswana. (It has three campuses, two of which are black whilst the Potchefstroom campus remains predominantly White Afrikaner and has successfully maintained the apartheid status quo. Such a merger was technically unimaginable and does not bridge the gap between the two merged institutions.

According to Dibetle (2008: 2) "the 2007 audit of the Council on Higher Education (CHE) criticized the faculty based campus policy and meant that students were or may not be able to study at their nearest facility and have to travel long distances and this became very expensive and, brought about serious friction between the central and local student representative councils." It must be placed on record according to Dibetle (2008: 1) that "the merger programme has not been a wholesale failure. There have been successes in a minority of universities but also tremendous failures." From observation of the mergers any move toward demerging universities will be very demanding and will be very difficult to implement today because the merger system has now been entrenched. Magasela Mzobe of the South African Student Congress (In Dibetle, 2008) is critical of the situation and said that "we feel that through the mergers, the government has failed in its distribution of access to higher education and it is important that we own up to our mistakes and stop blaming apartheid from everything wrong and that the government made a serious mistake." The mergers were pioneered by the late Minister of Education Professor Kader Asmal.

\subsection{The Historical Context of the Merger of South African Universities}

Since 1994 South Africa has been overhauling its entire education system as a part of a broader national reform movement aimed at overcoming the inequalities and polarization caused by the now defunct apartheid regime" Sedgwick, 2004: 1). The majority population for nearly 50 years was saddled with a system of racial separation, in all spheres of life including education and there was thus no free basic education. Everything was organized on racial lines and largely inferior institutions catered for black students. As a result of these inequalities many black students are ill - prepared for post - secondary education and this lingers on even today after 21 years of democracy. This has led to a shortage of skills particularly in management, science, technology, engineering and other fields of education. The road to reform according to Sedgwick (2004: 2) "through a series of mergers and incorporations aimed at collapsing 36 universities and Technikons (polytechnics) into 22 institutions. As a result, there are now three types of public higher education institutions 
in South Africa: traditional universities, universities of technology and comprehensive universities." According to the Department of Education (in Sedgwick, 2004) "the objective of the restructuring is to establish institutions that are better capable of meeting current job market demands, equalizing access and sustaining student growth." These noble goals have not been realized after 21 years of democracy. Universities are not able to meet the high demands of entertaining student applications for admission and many have fallen on the wayside. On the other hand the country faces a huge skills shortages, student performance in terms of entry requirements to tertiary institutions is dismal. Unemployment has increased tremendously, poverty has widened and inequality is rampant and performance of students in English, mathematics, and physical science has in reality decreased since 1994 (Mail and Guardian, 2015 - Various articles).

Comprehensive universities are a new type of institution resulting from the merger of Technikons with traditional universities. The objectives of this particular type of merger according to Sedgwick (2004: 3) are:

- To strengthen research in vocational, Technikon - type programmes.

- To give students a wider range of programmes with different entry requirements and to increase access to technical education throughout the country especially in rural areas where there is even today very little or no provision.

- To facilitate student mobility between programmes and to remove the barriers to further education."

All of the above in the main has not been realized and the situation is worsening when one considers according to the Mercury (2015) that "90 000 student applicants have been received by the University of KwaZulu Natal (UKZN) for less than 10000 places and at the University of Witwatersrand 150000 applicants were received in 2015 after the matriculation results were released for a mere 12000 available places at the university. This is the objective reality in South Africa, "which will add to the long line of increasing lost opportunities and increasing unemployment which stands at about 45 percent today (Karodia and Soni, 2013). This situation is the same at all other universities in the country. Although public higher education accounts for the lion's share of student enrollments in South Africa, a private higher education sector has emerged in the last 18 years. The 1997 Higher Education Act contains provisions that allow private institutions to offer degree programmes and limited Master's Degree programmes, provided that they are registered with the CHE and accredited by the Higher Education Quality Committee (HEQC). Given the admission problems in the country, the government has not fully supported private institutions in terms of subsidies and continues to over regulate these few institutions, in spite of them having met the requirements for registration by the authorities and some of them have made massive investments in respect of infrastructure and operate as distance education providers of higher education. They appear to over regulate private higher educational institutions and cannot regulate public institutions were standards in many have fallen. This aspect of greater support for private institutions must be urgently looked at by government because they provide both full time and distance learning programmes that in large measure could fill the gap that government is unable to fulfill at the moment and perhaps for a long period into the future. The South African government and particularly its Ministry of Higher Education has been shortsighted in not engaging these private higher education institutions, in order to partly fill the gap to educate those that cannot be admitted into public universities because of a shortage of entry spaces. Private higher education institutions have been engaged successfully by many other African countries like Botswana, Swaziland and Namibia including Mauritius and other countries. The lessons gained from these countries must be used by the South African Ministry of Higher Education. On the other hand, it is cheaper for students to study at these private institutions that can fill the yawning gap that permeates higher education in the country and will allow at least for a number of students who fall by the wayside to be accommodated into higher education.

Institutions of higher learning in the public domain continues to fail to fulfill their responsibilities as custodians of knowledge and skills production for purposes of socio - economic development and general transformation (SASCO, 2009:1) and by implication is in defiance of the Freedom Charter. Eleven years after the implementation of mergers, it has generated mixed feelings and in reality, their impact and outcomes remain unclear in as far as their objectives for which they were decided upon are concerned. It is also unclear in terms of the defined roles and contribution of both merged and unmerged institutions, in terms of the broader democratic transformation with particular reference to higher education learning and in this regard SASCO (2009: 1) states that "they have no option but to assume that the essential noble cause behind the mergers has been either compromised or betrayed and, in reality it has experienced a "mission creep" and therefore not bearing any results and therefore, after the lengthy period of implementation, it is necessary to start a process of interrogating the effects of mergers" (SASCO, 2009:1). It will therefore not be unreliable to say that, mergers have tended to be reductionist and academic in nature. 


\subsection{Lessons of Mergers from Around the World}

The SASCO document of 2009 pages 2 and 3 alludes to this aspect in the sense that mergers have been a feature of higher education for over 35 years now, especially in developed countries, which involves radical organizational restructuring or change. Amongst other reasons, publicly funded institutions of education tend to opt for merging as a strategy for both expansion and contraction. In China according to Harman (2002, in SASSCO) government uses mergers to address problems of institutional fragmentation, lack of financial and academic viability, and low efficiency and quality, and to build larger and more comprehensive universities. Between 1991 and 2001, 40 mergers were completed in which 104 institutions were reorganized into 40, by 2004 institutions of all types had been involved, with 382 institutions created" (Yang, 2009, in SASCO). Yang (2009, in SASCO) further points out that "from the government's viewpoint, merging several complementary institutions to form a new and comprehensive university gathered the strengths of different institutions and at the same time avoided unnecessary duplication and, thus seemed to be a more cost effective way to reach the world - class university objective. Higher education institutions had to respond to these changes in government policy, either to survive or to grow." In Sweden, a country with more than thirty five years of experience of handling the trend, the merging universities continue to unravel challenges and problems, but there are important lessons to draw from the Swedish experience. "Institutional mergers in Sweden according to Bladh (2009 in SASCO) "are motivated by passion for collaboration as opposed to the Chinese's "arranged marriage" approach. Institutions in Sweden had the objectives of strengthening the quality of undergraduate training, increasing research funding and making management more effective." Thus, in order that mergers are successful the following must prevail in order for mergers to be successful according to the literature cited by Bladh (2009, in SASCO). These are:

- There must be a shared vision of the future and the possibilities for change.

- Unchanged leadership during the process is advantageous.

- There needs to be mutual confidence between the institutional leaders involved.

- There has to be a broad level of support for the merger inside the institutions, including from students.

- Support from local and regional political levels and the regional business sector facilitates the process.

- The name of the new institution is crucial and a new name must be acknowledged by all stakeholders at an early stage, is highly recommended.

- There must be no or very little political interference when the processes are being engineered.

- Transformation and mergers must be guided by defined policies and must not be arbitrary.

- Government must evaluate and monitor the implementation processes.

- There has to be no interference by labour unions in general. They need to play a monitoring role only.

- The mergers should not be polarized into a political tool.

- Necessary resources must be provided in order to attain success.

- The system should not be engineered to allocate academic positions to those with the minimum amounts of academic experience and so on.

- A host of other important factors and variables that is important to mergers of universities.

In South Africa, not all of these benchmarks were used but unfortunately the benchmarks from international experience, were not cogently followed through and parochial interests reigned supreme from both white and black constituencies and, the situation of mergers became highly polarized with much political interference and engineering of the merger system (These benchmarks are alluded to and named elsewhere in the paper). There was much resistance on the part of those driving the processes of mergers. The reluctance within which most of the institutions entered into mergers suggests that, it was mere acts of malicious compliance which lacked both commitment and patriotism" (SASCO, 2009: 3). The relationship between education and development is a historical one. As societies develop, education must be accorded a central role as the driving force for industrialization and economic development. This impetus was not fulfilled and is still not fulfilled in the case of South Africa post the 2003 implementation of merger initiatives. It is crucial to understand and appreciate that the South African restructuring of higher education is unique, to the extent that it was and is still driven by a political agenda of transformation, redress and equity. It is therefore necessary to understand the critical aspects of review and effects and outcomes of the mergers within the context of a democratizing society because of neoliberalism. Given the historic divisions that constituted the entire social fabric of South Africa, from apartheid and, which continues even today under a democratic dispensation and, is therefore, manifested and grounded in terms of race, class and ideology. It has to be placed on record that there have been achievements but at the same time many failures and overt challenges that need to be confronted (The paper does not explore these failures or achievements). The SASCO document (2009: 10 to 11) alludes to the following macro 
conclusions and recommendations. These are as follows: (Listed but not discussed).

\subsubsection{Broad Conclusions}

- Quantitatively, the mergers tend to undermine demographic transformation goals.

- Qualitatively, the mergers are failing to address the skills mismatch in the labour market.

- Lessons from other transformation projects were not seriously factored into the merger equation in South Africa.

\subsubsection{Short-Term Recommendations}

- A commission of enquiry or a review process into the effects and impact of the mergers must be instituted with urgency and, must provide answers to the following:

- Was it a correct strategy to merge institutions and leave some of the historic apartheid universities intact?

- The role of business and the private sectors role in the merger equation were not defined.

- Whether the mergers have achieved their objectives as set out in various policy frameworks.

- Have the mergers really allowed for access to higher education, and to black citizens who were historically marginalized and disadvantaged.

- Determine the challenges that require intervention and identify the grey areas that derive from the merger process.

- Other issues that have not been dealt with and, to cogently learn from international experience.

- Re - consultation with all stakeholders that have a direct stake in South African higher education.

\section{Exemplifying and Recalling the Merger Mess at the University of Kwazulu Natal}

Michael Cherry (2014: 39) states that in February of 2014 "the government gazetted the report of the ministerial committee for the review of funding of South African universities. Its most important finding was correcting through weighting the number of academic staff and the research output of the universities." He further adds (2014) that the "top cluster includes five usual suspects, the Stellenbosch University, the University of Cape Town (UCT), Rhodes University, the University of Pretoria and the University of Witwatersrand (Wits), but no longer the University of KwaZulu Natal (UKZN). Notably included in this top cluster are two historically disadvantaged institutions of the Western Cape and Fort Hare." The remarkable thing about this cluster is what separates the top five from the bottom two: those five were largely untouched as pointed out earlier in the discussion by the merger plans implemented, a little over a decade ago by then Education Minister Kader Asmal during the era of the Thabo Mbeki government. UWC and Fort Hare, together with Rhodes University, were earmarked for mergers in Asmal's original proposals and escaped after intense lobbying by their respective vice - chancellors. We are not dealing with these successes but rather the depressing story of the -post merger history of UKZN. This is an example that can be looked at and from its problems and, can be extrapolated to other South African universities that were merged.

Michael Cherry (2014: 39) reports that "academic freedom has been seriously compromised at UKZN and all of this has had very serious repercussions for the merger at the university because of the dictatorial behaviour of the former vice - chancellor. The university has seen blatant interference and restructuring with staff losing their jobs at the whims and fancies of the university administrators which has caused serious problems in the past with the merger exercise." There has been a misguided attempt by the former vice - chancellor to purge academics and to Africanize the university at staff levels which saw droves leaving the university together with seasoned White and Indian ( The latter race group is also defined as black and designated as such by government frameworks, but they are totally ignored and, is a case of reverse racism in many ways) academics being trampled upon in spite of distinguished and outstanding academic service. Racism has reared its head at the university and the authorities led by the former vice - chancellor (Makgoba) began to employ a number of African academics from African countries, with many not in tune with South African politics and its education environment and, many do not have the relevant experience. This racism reared its head at the university's medical faculty when outstanding Indian academics were accused of failing black students. There was not one iota of truth in these allegations, as was proved by a commission of enquiry instituted by the university and the government. The academics were not prepared to lower academic standards. This was the long and short of the uncalled allegations. Tried and seasoned medical academics resigned from the medical faculty to the peril of the institution. This 
reverse racism has become entrenched at UKZN and will now be very difficult to eradicate and, will have devastating consequences in the future. More importantly, it goes against the grain of the South African liberation struggle and moreover government authorities within higher education and the ANC led government have not dealt with this situation with the contempt that it deserves and made no efforts to bring the former vice - chancellor (William Makgoba) to book and order for causing and fuelling these tensions. There was an over zealousness to Africanize the institution with no sound action plan and strategy. This has led to a drop of academic standards, the marginalization of South African minorities at the university. In fact there is nothing African that has emerged at this university in spite of its slogan that it is an African university of excellence. In addition under the former vice - chancellor the University of KwaZulu has left a trail of massive debt running into billions of rands. It would be most difficult for the university to emerge from this quagmire.

The story of the merger at the UKZN as outlined in John Higgins recent book, Academic Freedom in a Democratic South Africa: Essays and Interviews on Higher Education and the Humanities, covers many of the same issues described above in more theoretical terms. The story is an important one, because UKZN is the result of a merger between the former universities of Natal and the predominantly apartheid created University of Durban Westville which in the days of apartheid, catered for the higher education of the Indian community of South Africa. This merger saw the creation of one of the largest residential universities in the country. Importantly Michael Cherry (2014: 39) points out that the Higgins book "includes a discussion of both the Higher Education Act of 1997, which is viewed as being pernicious in having enabled the corporatization of South African universities, and of the context in which the ill - fated mergers took place. On assuming office in 1999, the former Minister of Education Kader Asmal commissioned the Council for Higher Education (CHE), then still a credible body, to report on the size and shape of the universities and technikons." Its 2000 report made the sensible recommendation that the sector be differentiated into three categories of institutions as follows:

- Those offering the full gamut of under - and postgraduate degrees up to PhD level.

- Those offering only up to master's degrees in certain fields in which they had expertise.

- And those offering only undergraduate degrees (In Michael Cherry, 2014: 39).

Rather than acting on these recommendations, former Minister Asmal chose to follow a time - honoured tradition of 46 years of the apartheid National Party rule by binning and disregarding the report. Instead he commissioned a plan to put together a merger plan for universities. The commission consisted of politicians including the former vice chancellor of the UKZN under whose watch racism, witch - hunts and gross mismanagement became the order of the day and this reverberates within UKZN even today, almost to a point of no return. When William Makgoba according to Michael Cherry (2014) "was appointed vice - chancellor of the University of Natal in September 2002, the Merger with the University of Durban Westville was already on the cards and he articulated the view that the merger could be a vehicle for transformation, but he was in an unenviable position as neither the merger nor his appointment had the support of the university's senate." Since the merger in 2004, UKZN has been the subject of serial controversies, which are chronicled in Higgins book. By 2008, the university was looking to the CHE's routine audit for purposes of salvation. The CHE audit conducted by Martin Hall as chairperson described the former vice - chancellor (Makgoba) as an authoritarian and that this behaviour was most problematic.

Interestingly and without any objectivity and more importantly without any moral fibre and integrity, the $\mathrm{CHE}$ ignored Hall's concerns and instead set up a review panel. Astoundingly this panel's recommendations were made available in December 2010, after a protracted two years that had lapsed. The review played the tune of the CHE and by implication the tune of the government, in that they chose to ignore Hall's concerns and affirmed that the audit report meets international standards of "quality assurance practice" (the review panel consisted of Thoko Mayekiso, Mark Hay and Mashupye Kgaphola). What the review panel overlooked was the important and fundamental variable that Makgoba's involvement compromised the independence of these entities and that Makgoba's claim that Hall's letter had affected the contents of the report should have been overlooked by the review panel. In reality the review panel lacked objectivity and in many ways compromised higher education and the merger process at UKZN. The consequences of the effects of the review panels decision on Makgoba and its negative effects upon transformation has affected the university of UKZN and its effects reverberate even today. It points to the fact that when good people lose their moral fibre they contribute to the failure of democratic institutions and this was exactly what happened under the watch of the review panel. On the other hand and the fact that no one other than the CHE itself could be held responsible for taking so long to decide to suppress the report appers to have escaped its chairperson, Chabani Manganyi. There is no doubt that perhaps this was the most unsuccessful of the mergers. Some would argue according to Michael Cherry (2014: 39) that "corporatization is an inevitable consequence of universities becoming too large to be run as collegial institutions."

Merged universities are not necessarily more corporatized than others. They are still larger than their antecedents. The question that must be answered is that given its urban setting and past sound leadership could UDW which produced outstanding professionals over the years and indeed many academics second to none, in the country and, who have 
performed outstandingly in respect to research and, on the international stage, should have had a similar path to the University of the Western Cape and the University of Fort Hare? The answer to this should have been a categoric yes, but the interests of the country were put aside and UDW was compromised and, its traditions broken in spite of it being termed a "Bush College." it was, there is no doubt a seat of excellence in spite of apartheid oppression. This would have not allowed the former vice - Chancellor William Makgoba, to successfully inflict upon the merged university; if the merged UKZN was not straddled by the unpleasant blend of corporate authoritarianism, racial polarization and the destruction of a seat of excellence by the authorities in charge of education transformation of higher education and the imposition of the former vice - chancellor Makgoba, who in reality was inept and did not understand a changing South African educational landscape that required inspired leadership. Rather, the former University of Natal and the former University of Durban Westville should have never been allowed to merge but, should have remained independent and autonomous institutions in their own right. This is further strengthened by the argument that in a relatively short space of its existence of about 30 years, it became an outstanding seat of academic excellence and competed on uneven terms with the privileged essentially White University of Natal that was in existence for over 100 years. This short sightedness has come back to haunt the failed merger processes of university amalgamations and some of the appointments of vice chancellors have in reality destroyed higher education. This has been a travesty of justice.

\subsection{Poor Decisions, Internal and External Politics have Caused Damage to Ukzn's Merger}

Chetty and Merrett point out that merging universities was an easy option for the government during former minister Kader Asmal's tenure from 1999 to 2004. Mergers were costly and were an expedient solution in many ways by transferring political tensions to the newly created universities. In actual fact the details should have been left to the universities themselves rather than misguided political imperatives." Patrick Fish (In Chetty and Merrett, 2014) states that "the history of university mergers was neither transparent nor carried out for any of the reasons that usually lie behind a merger; they failed to achieve efficiencies or financial economies of scale and probably cost the taxpayer because no significant part of a partially rotten system was closed down." In reality government sought to transform the sector out of the inequalities of the past and in the process forgot to transform the sector into anything" (Mail and Guardian, 2009). In reality the realities were ignored conveniently by the authorities in order to change everything that was formed under apartheid and mergers merely turned out to be an exercise of social engineering and political agendas. In many instances there was no empirical evidence to substantiate intervention strategies such as cost and other efficiencies. Literature indicates that the best universities are small ones and therefore distorted geographic perceptions were also employed in the South African mergers of universities. There was an indication of paranoia. Further thought and planning like happened with the University of the North West was not allowed for UKZN. The reality is that politicians think in the short term and in the case of UKZN there was a desire to destroy what had existed before, regardless of its quality or functionality. There was no collegial governance at UKZN and scuppered the efforts to create a democratic society built on inclusivity and thus entered the realm of internal control and thus was at odds with the purpose and functions of a university.

Chetty and Merrett (2014: 45) point out that "sheer inefficiency typified the merged university and frustrated the most basic of day - to - day activities. Centralization and a lack of proper management were joined by a complete authority of control on the part of some administrative offices such as the central buying office, which usurped roles and destroyed supportive roles. One of the most contentious aspects of the big - picture executive managerialism involved the salaries and performance bonuses paid to the elite who were now in charge. Salaries spiraled out of control and lower end staff was compromised while the upper echolons became millionaires. Pay package at the universities of Cape Town and Witwatersrand were far more modest than UKZN. These intervention differentials were applicable to the private sector but were inappropriate to educational institutions but were a reflection of what was going on in the country. It was an indication of a free for all with no recourse to development and service to the nation or consolidating democracy for the success of the country."

\subsection{The Focus By Universities Should Be On Creating A More Democratic Society}

William Gumede (2014: 42) indicates that "African and South African universities and institutions of higher education must redefine themselves away from being 'ivory towers' and with a greater sense of purpose pursue a new democratization mission of their societies given the failure of political leadership in order to entrench genuine democracy." In other words education is not only a vehicle for the transmission of values, but must also reproduce values. Universities should therefore be places of interaction and ideal places to foster new common democratic values and to actively defend these 
democratic values. In general in the South African context this has not been achieved in post - apartheid South Africa and the merger of universities has not helped this process. These institutions must be autonomous and must create a mutually beneficial relationship with the state, society and all stakeholders. In short universities in the emerging democratic order in South Africa must become more relevant to their societies. Agreement must be reached with social partners in respect of common objectives and institutional independence must become the order of the day. Given the young emerging democracy in South Africa and the consolidation of new democratic orders in Africa, this is a difficult task to entrench, but efforts in this direction are important more than ever before. William Gumede states in this regard that "often universities in the region have either docilely followed what politicians said their resource output should be or, to prove their independence, have stayed aloof, often not only from governments, but also from societies itself." The merger of universities has not assisted this important process.

Universities must start to question undemocratic societal routines, leadership behaviours and values it is likely that they will come under attack from politicians and entrenched interests. This has happened in South Africa after merger of universities aided and abetted by appointed and handpicked vice - chancellors and university administrators who tow and push sometimes the misguided imperatives of government in respect of policy imperatives that compromise academic freedom and the empowerment of society as a whole. The notion of embedded autonomy must become a reality in order to insulate democratic principles, autonomy and academic freedom, which was stifled during the merger process in South Africa. Every issue can therefore not be reduced to racial reasoning. Often, we find as Gumede points out (2014: 42) that "undemocratic and corrupt African leaders often appeal to black authenticity, which demands a closing of ranks behind black leaders only because they are black. Racial reasoning must be replaced by moral reasoning, to understand the black freedom struggle as a matter of ethical principles and wise politics." Under the former vice - chancellor Makgoba, this was overtly compromised during and after the merger of UKZN. Critical minds must be produced by universities and must produce also decision makers who must have the ability to determine social behaviour of citizens. Universities in the country must produce graduates that are socially conscious with a greater sense of public duty and empathy.

In the post - apartheid period, higher education institutions in South Africa must stand for the values of democracy and must not align themselves with political parties but oppose undemocratic practices by ruling parties, opposition forces and civil society. Indeed, there are a host of other issues that encompass this particular discussion that goes beyond the scope of this paper. However, in this regard in order to respond effectively to the challenges of democratization, universities will need stronger internal governance systems. Academic freedom must be become a norm at both individual and institutional level which has been seriously compromised during and after the merger of UKZN. Accountability and efficient management must be entrenched at universities. However, it is important that government and regulatory authorities put into place targets in respect of access, high fees that must be curbed, appointment of staff at the both the academic and administrative levels, in order to bring about equity must be monitored and a lack of meeting defined targets must be death with very seriously. The status quo nearly 21 years down the road of democracy cannot be allowed to continue unabated. All of this must guarantee university autonomy, provided university vice chancellors, their top management and University Councils are held accountable to serve the interests of higher education in South Africa. Autonomy of these institutions is necessary but more importantly it will allow for a change of apartheid demographics which is long overdue.

\subsection{Abuse Of Power And Authoritarianism}

In this regard Chetty and Merrett (2014: 46) show how "the reckless and unreasonable exercise of power at the highest levels of the University of KwaZulu Natal (UKZN) was illustrated by the so - called Desai affair, which had international repercussions. In 1966 Ashwin Desai was a sociology lecturer and union official at the University of Durban Westville at a time of discontent about retrenchments and outsourcing. A disciplinary process resulted in the termination of his employment and a ban of his presence on the Durban Westville campus without the express permission of the vice chancellor." Seven years later, Desai was appointed honorary research fellow at the Centre of Civil Society of the University of Natal; and in 2003, his ban was lifted by the new vice - chancellor and the following year the centre became part of the new University of KwaZulu Natal.

Chetty and Merrett (2014) point out that "Desai since the 1990's had been involved at the interface of community organization and academia, specializing in environmental and trade union issues in south Durban. In 2005, he obtained research funding from the Human Sciences Research Council but was told by UKZN to apply for a contract post to pursue his work. However, the selection committee did not appoint him and he was denied his honorary post. Vice chancellor Makgoba's reason for this was that the previous vice - chancellor had only suspended the ban, not removed it. There was, he said, no document to prove the latter." Unbelievably for a man at the helm of a supposedly brand - new 
institution prone to discount the past in all its components, he argued that the Durban - Westville ban was irreversible, and that affected the honorary post as well, strangely, as a vice - chancellor who appeared to exercise enormous power, he declared himself mysteriously powerless in this context. This is where democracy and academic freedom were compromised and in many ways tainted the merger exercise and the overt abuse of power with no check and balances to basically home in upon a tyrant with a huge ego and who had government support. This is the same person (Makgoba) who embellished his false curriculum vitae when he applied for the position of vice - chancellor of the Witwatersrand University and was denied appointment rightfully, could be appointed at UKZN to the highest position and the government stood by and supported this tyrant.

Chetty and Merrett (2014) state that "Desai described Makgoba's response as "semantic nonsense and ascribed it to personal animosity. Among the international protesters were the high - profile Noam Chomsky and Naomi Klein, who with 400 other objectors signed a petition. The Committee for Academic Freedom in Africa asked Makgoba to reconsider his stance. All agreed that the episode was a blatant attack on acade4mic freedom." This is the type of person that was placed in charge of transformation at UKZN, a person who has tarnished thy reputation of the university and that of South Africa on the international stage. The vice - chancellor denied this and alluded to in racial terms that the committee was led by non - Africans, living out of Africa, little realizing that this had nothing to do with the case and that he Makgoba is a narrow - minded academic with little experience and ac "Johnny come lately to South Africa with a limited track record politically and little experience as a university academic and administrator and steeped in a lack of the tenets of understanding justice and academic freedom. Chetty and Merrett (2014) quoting Desai state that "Makgoba had been found guilty of serious misconduct in the past and had failed to respond to Makgoba's request to lift the confidentiality clause that was part of the original Durban - Westville agreement about the end of his employment there. Racially he attacked Indian journalists and Makgoba blamed the merged institutions. In other words he is involved in intellectual gangsterism and has turned the UKZN campus into a den of tribalism and radicalizing issues to serve his parochial and inferiority complexes." Desai said (In Chetty and Merrett, 2014) that "but for the fact that Makgoba is African and deploys this quality as a pre - emptive cover for his mismanagement of the institution, he would have been laughed off campus long ago."

\section{Transformation Is not the University of Cape Towns Priority}

Analysis of this premier South African university - Cape Town reveals that it claims working for change in terms of the racial demographic of its staff, but nearly a decade or more after the post merger of universities in South Africa, the direct opposite is observed. There is therefore no doubt that arguably quality in South African universities has been compromised for a long time. In this regard staff transformation at South African universities has once again made it back to the headlines of newspapers, with a focus on the University of Cape Town. (UCT). "UCT sometimes receives a disproportionate amount of criticism relative to other institutions that are quietly getting away with failures in the same areas and of the same dimensions. A good example is its much =- criticized affirmative admissions policy and many South African universities have equally poor racial representation according to Sean Muller (2014: 42). Given that the merger exercise of universities in South Africa has now gone on for a protracted period of time and that the main objective of mergers was to bring about transformation of the higher education landscape in South Africa, it is an indictment to the democratic government, its ministry of higher education and indeed many of the traditional former White apartheid traditional universities that transformation has moved very slowly and is steeped in maintaining the apartheid status quo. There is therefore no doubt that after nearly twenty one years of democracy and racial skewedness in almost all facets of South African higher and basic education, most academic institutions could do much better in respect to staff transformation. With Regards UCT Sean Muller (2014: 42) states that "he agrees with many critics of UCY vice chancellor Max Price's recent articles, in which he claims that UCT has been doing a lot for transformation and that other universities have done better only because they had inadequate regard for quality. By the same token former white institutions should have done more to change the demographics of their staff complement, while some others have succeeded in transformation by numbers, but have failed in substantive transformation."

Sean Muller (2014: 42) states that "the claim that UCT has been making concerted efforts to transform is, as far as he can ascertain, false. Pinning UCT's failures on a concern for quality is disingenuous and damaging. Of course there are thresholds above which trade - offs occur. It seems unlikely that UCT could achieve a nationally representative academic workforce in a year without compromising on quality. But the use of extremes to defend UCT implies the institution is doing all it can to facilitate transformation, but this certainly not the case." It is obvious that the blame for all of this at UCT and other South African Universities both the traditional apartheid institutions that were protected by the merger mess and also the former Bantustan black universities must be laid at the feet of the government and its 
regulatory and monitoring institutions, university departments and faculties themselves. In other words there is inadequate evidence of transformation in general in respect of higher education. "The uncomfortable truth is that senior management at UCT has failed to make transformation a priority, in a recent public debate on the matter, Price acknowledged "a lack of urgency," but one could go further and say that there has been little emphasis on the issue at all. On the other hand South Africa hears very little about academic mediocrity, but a great deal about how transformation may compromise quality (Sean Muller, 2014: 42).

Arguably quality has indeed been compromised for a protracted period of time. It must be recognized that it is appalling that young black academics are struggling to obtain junior positions for which many of them are better qualified formally than some members who have been appointed and better qualified than members of their hiring committees. It is thus obvious and necessary to appreciate and fully understand that separate transformation in terms of hugely inconsistent standards across generations. Another aspect that requires urgent attention is the empowerment of staff in respect of quality research, which requires commitment, finance, joint partnerships, international exposure, planning, energy, initiative and above all defining the type of research that must be conducted at universities and support of the research initiatives of recognized and accredited private institutions of higher learning and education. Observation reveals, in that the writers are researchers at a private higher learning institution, which receives very little support from government and that many initiatives within both the private and public institutions are ad hoc and undertaken to empower a few and to paper over the cracks; they are of limited scope, mostly externally initiated and weakly driven, without a sense of direction to serve the interest of South African development initiatives and does not serve the country to deal with the issues of unemployment, inequality, poverty, industrialization, innovation, entrepreneurship, sound agricultural practices, the promotion of applicable scientific research and the promotion of the humanities. It must now be recognized by South Africans that no one from outside will nurture this imperative and spirit because it has to be home grown, and therefore, the theorizing about affirmative action after 21 years of democracy must now stop, although it has been a start, the time has come for concerted action but thus far, all of this has far from enough to achieve sustained, coordinated and necessary institutional change.

Twenty years down the road to democracy and into the second decade of the merger mess of higher education, there is no detailed evidence on staff dynamics is lacking. The false notion often put forward is that it is difficult to retain young black academics because academic salaries are low relative to other options. This has been the argument of the white establishment but very little evidence to support this claim could be unearthed. Low salaries are a universal phenomenon and not peculiar to South Africa. By international standards Sean Muller (2014) states that "salaries at South African Universities appear to be quite competitive by international standards." Another very serious problem that confronts South Africa is the "desire by many traditional university hierarchies to maintain older staff, unreliable funding for postgraduate study, the compromising of merit in appointments of academic and other staff, higher demands on new academics, variable quality of PhD supervision, dependence on patronage of senior academics, various policies at both the institutional and national level systematically maintaining the status quo and discriminating against new academics" (Karodia, 2013). There has to be a realization by government that they are being hoodwinked by those that they rely upon in that, there are many institutional policies that hinder transformation, for example, the Eurocentric approach that academics cannot be sole supervisors of a PhD unless they have supervised before. There is no doubt that UCT and the historically advantaged universities have not demonstrated a link between a history of supervision and supervision quality.

The traditional white former apartheid universities have made claims about efforts at transformation that have in the main been misleading to the citizens of this country but more importantly to outside formations on the international stage. These universities can provide no empirical evidence on a host of policies and their successes to deal with the opportunities provided to young black aspirant academics. Sean Muller (2014: 42) points out that "UCT does not conduct exit interviews and there is no systematic, university - wide efforts to communicate these findings and to do anything constructive with them." He further adds that there the efforts of equity training is highly questionable. There is thus no doubt that something is amiss in terms of senior management at many traditional white former apartheid universities and the day to - day practices leave much to be desired. There is no doubt that all of this falls within the intervention strategies of the government. It requires government to reassess the merger mess and indeed the maintenance of the status quo, which is harming higher education in South Africa. This analysis in many ways proves that merger of universities have not really created and environment for promulgating South African higher education and its universities to enter the $21^{\text {st }}$ century with confidence and in the interest of the sum total of the population, given South Africa's apartheid history. 


\subsection{Enlightened Leadership Required}

Michael Chapman (2014: 38) states that Higgins poses two interrelated questions in his book. What is or could be or should be academic freedom, both in South Africa and, by implication, globally; and what is or could be or should be the role of the humanities"? Academic freedom in South Africa is defined constitutionally not as an institutional practice, but as an individual right. One may pursue knowledge for its own sake; and engage, even contentiously, in the debates of the academic discipline. In this regard, we analyse the issue from Higgins perspective (refer to his book). "It is crucial that individual freedom can distract attention from the real dimensions in which academic freedom operates: the complex and politically charged exchanges within institutions between academics and the new managerial class of administrators; the struggle between universities and the state in relation to the control of teaching and research priorities; and the all encompassing ideological battle between liberal and neoliberal ideas of the very purpose of higher education, which most commentators prefer to pretend is not happening." In short or other words, universities have come to embody an organizational or managerial culture. The new managerial class consists of retreaded academics, whose tasks are no longer to teach or research, but to monitor the teaching and research of their former colleagues. No longer elected by their departments Michael Chapman (2014) points out that "that they are no longer elected by their departments, faculties or schools, the new managers owe their primary allegiance as well as their big salaries to the vice - chancellor's authority over his or her senior executive team." This is a major problem and the merger of South African universities did not take into account that such a situation was a breeding ground for autocracy and authoritarianism in many universities were the vice - chancellor became all to powerful and ran the university and made appointments at his own whims and fancies as was seen at UKZN under Makgoba and became and entrenched practice and phenomenon, which compromised academic freedom and a host of other variables. This has led to a collapse in standards, fear, patronage and fear that has eroded the very fabric of higher education. This has become a feature of many university establishments in South Africa. This has compromised higher education to almost a point of no return and has bred mediocrity.

This has led to a "them versus us" scenario which have become a commonplace and often purported to be a market paradigm, the professional disciplines flourish while the humanities are marginalized, that is, the nonvocational humanities, such as literature or philosophy, as distinct from say, psychology, law or economics" (Michael Chapman, 2014: 38). This is a summary; Higgins arguments are informed by a subtle context of ideas and history and he identifies the value of critical literacy as a key humanities intervention in utilitarian times. It must be recalled that former Minister of Education Kader Asmal had without intellectually understanding the importance of the humanities to a new democratic South African education order post 1994, had relegated the humanities to the dustbin in his transformation efforts. This has had serious implications for South Africa and for higher education. Noble laureate and Higgins erstwhile colleague J. M. Coetzee, whose letter to Higgins serves as a foreword to his book ("Universities head for extinction)" stated that "the fact is that the record of universities, over the past 30 years, in defending themselves against pressure from the state, has not been a proud one" (Herein lies a direct attack upon the failed merger process). Few academics appreciated this scale of attack and rightfully so. Michael Chapman (2014) in this regard states that "whereas the National Party, between 1948 and the late 1980's had a conception of the state to which such tenets of British liberal faith as academic freedom were simply alien, Coetzee (in Chapman, 2014), posits that "the indifference of the African National Congress (which is the ruling party and leads the South African government) to academic freedom has less of a philosophical basis, and may simply come out of a defensive reluctance to sanction sites of power over which it has no control". Again we see that a lack of vision within the merger process and ill defined goals of the merger process, the ANC has created an environment that has maintained the apartheid status quo, reduced higher education to the lowest common denominator and in so doing created an environment of authoritarianism and failed to defend academic freedom which compromises its struggle credentials. Chapman, (2014) points out that a former Minister of Education Naledi Pandor indicated "her disdain to the phrase speaking truth to power. She criticized this overtly but misunderstood that the language that the humanities had to offer to policy makers in order to contribute to the government's vision of a prosperous, non - racial nation."

From the above, one can glean that Pandor's invocation of vision is instructive. Instrumentalization, bureaucratization or utilitarianism in South Africa have long operated in tandem with grand, often delusional visions, for example, Anglicization of apartheid, separate development and now the overlapping hankering after a socialist utopia and capitalist productivity or, in other words, a national democratic revolution. The essence of all of this is that if the ANC and some of its former Ministers of Education did not understand the fundamentals in terms of the reconstruction of higher education, they could not offer the required leadership that was necessary to intervene during the merger processes and thus contributed to the failed merger modalities and allowed the status quo to remain which has had tremendous repercussions for higher education in a democratic South Africa. Technically, professionally and ideologically all of this has contributed to a dysfunctional higher education system in South Africa. It would now be most difficult to redress in a 
short period of time these fundamental errors that have annihilated at least two or more generations of South Africans from the predominantly disadvantaged groups that have been crying out for change and higher education opportunities since the dawn of democracy in 1994. This according to Higgins (In Chapman, 2014) has led to the reality that "in the educational sphere, cost efficiency seeks to coexist with the ideal of massification; developed world imitation (as in outcomes - based education - now scrapped in spite of past criticism that Asmal and the government did not heed) founders on the reality of developing world under - preparedness. If the law of the professors has been replaced by the law of the managers, then the law of both the professors and the managers is regarded in government circles as subservient to the law of the ANC party political power."

Higgins many arguments in his book underscores the point that Margaret Thatcher's Education Act of 1988, which in terms of funding, shifted the legitimating idea of higher education from a focus on serving the public to one on servicing the economy. This has played directly into the hands of neoliberals, the capitalists and has distorted the well defined policies on the table in terms of the reconstruction of higher education in a post - apartheid South Africa. The issue is whose interests is the ANC serving and indeed it is in bed with neoliberals and capitalist classes and forces much to the peril of the poor and the masses of South Africa. In this regard Chapman points out (2014) that "a business model became entrenched under Thatcher as is now happening in South Africa under ANC rule (Robin Renwick, 2015: 15). Thatcher much like the ANC was hostile to critique and this cannot assist transformation nor any new engineering of the failed merger mess and reduces the merger exercise to an exercise defined on ill conceived modalities of the ANC. This puts paid to the much required tenet of academic freedom, in terms of pursuing the debates of the discipline from the freedom of critique and the functioning of institutions, which automatically leads to a business - organizational culture of bringing institutions into disrepute and not serving the interests of South African educational development. In this regard (Higgins, 2014 in Chapman) states that "if this in South Africa seems foreign to the pre - Thatcher English way, it was not unusual for the former Afrikaans institutions under apartheid to toe the government line. Neither is it unusual, today, in British, North America or European universities to have ascendant managerial class. This leads to firing academics and people who criticize management at South African universities as was seen under former Vice - Chancellor William Makgoba at UKZN. The issue therefore arises - Do questions of academic freedom in South Africa amount to little more than our catching up with the rest of the world?

What is frustrating is that, in a post - apartheid South Africa predicated on human struggle, the educational regulations, Acts and policies fail to follow through on any intrinsic intention and that the merger exercise has not helped at all. It is thus obvious that given the different scenarios discussed in this article both locally and globally, universities will continue to be governed by the law of managers and in South Africa grand visions, usually politically inspired will continue to contradict everyday reality (Christo van der Rheede, 2015: $1-4$ ). This leads to the reality given globalization that planners will be distracted from local realities.

In reality and through observation during the first 21 years of South African democracy leadership is poor at universities, as in the old South Africa under apartheid, and also under the new dispensation, talent leadership is uneven whether in government, business, the media or, in institutions of higher learning. Without enlightened leadership in universities, the worst of managerialism, the fear of independent, innovative thought, a refusal to listen; a default mode of authoritarianism will define and infect the character and practice of the institution and academic freedom is unlikely to feature on the agenda of transformation. South Africa deserves better but this seems to be a distant dream and mirage under the current government and indeed the narrow and poor leadership being exhibited by management and hand picked vice - chancellors of South African universities.

\section{Neoliberal Policies}

Steven Klees (2014: 36) in reviewing the new book edited by Salim Vally and Enver Motala, Education, Economy and Society (UNISA Press) offers an in dept critique of the concepts, frameworks, interventions and logic that underlie much of South African education and training policy. The book offers a critique of the three basic discourses that are used to support education and skills solutions to current problems. The mismatch discourse goes back at least to the 1950's. In it, education has been blamed for not supplying the skills that business needs. This mismatch is about vocational skills. Underlying the skills discourse is the human capital discourse. In the 1950's and earlier, the neoclassical economics framework that underpins capitalist ideology and practice could not explain labour." The advent of human capital theory in the 1960's offered a way to deal with labour in terms of supply and demand, as a commodity like any other. The book argues that human capital discourse and the knowledge economy has been one of the most destructive ideas of this century and the one before. It is against this background that the authors state that finding a solution to the triple challenge of poverty, inequality and unemployment has been unproductively directed towards addressing the lack of 
individual skills and education instead of focusing on capitalism and other world system structures, whose very logic makes poverty, inequality and lack of employment commonplace.

Underlying the human capital discourse Steven Klees (2014) points out that Vally and Motala state that "most directly since the 1980's has been the neoliberal economics and that the discourse recognized some of the inequalities inherent in capitalism and argued the need for government interventions as a corrective." This aspect was not factored into the merger discourse of universities in South Africa. Motala and Vally (In Klees, 2014) point out that "with political shifts exemplified by Ronald Reagan in the United States, Margaret Thatcher in the United Kingdom and Helmut Kohl in Germany, a neoliberal neoclassical economics discourse took over, which argued that capitalism was both efficient and equitable, that problems were generally minor, and that the source of any problems was too much government interference." The discourse in South Africa has gone beyond economics and has political, social and cultural dimensions. In education, the upshot of neoliberal discourse has been to ignore the problems faced and thus to promote market solutions in a society that is undergoing very serious transformation. This denies access to the education system. The value of education is reduced to economics. This fundamentally contradicts the essence of education and they state that "once the commodity value of people displaces their intrinsic human worth or dignity, we are well on the way to a state of barbarism" (Vally and Motala. 2014). They further argue that neoliberal capitalism is also racialist capitalism, patriarchal capitalism, plutocratic and monopoly capitalism. These are issues that have not been clearly understood and articulated by government and have impacted negatively on all education in South Africa. For example, the left has been accused has having a conspiracy theory approach of understanding capitalism's operation and motives. The World Economic Forum is meetings of the global ruling elite in an undemocratic forum to decide on global policies.

The question that Klees (2014) poses is - Can capitalism be improved, be fair and just? It cannot be tamed in the broader social interest Vally and Motala (2014) argue. "They further argue that greed and inequality promoted by capitalism, the racialism inherent in it coupled with sexism and environmental destruction and thus promotes a resistance to change. Governments captured by elites and by unequal logic inherent in the world system, can only with great difficulty offer significant challenges. All of this is a long haul of a just struggle and the South African higher education system coupled with its inept transformation and indeed failed merger of universities does not lend itself to sustained discourse to address this challenge because South African government policy has been highjacked by neoliberal and capitalist forces and is steeped in overt patronage and corruption. The outcome of all of this is indeed a, long haul in South Africa and higher education sits on the precipice of disaster because of the inability of the government to bring about meaningful and acceptable transformation of education. The struggle to transform education, reengineer the failed merger scenarios that the country has been forced to accept and which has damaged the education landscape and the aspirations of the masses, the struggle for change in health, food, water, environment and development must continue in South Africa because of the neoliberal policies of a government that has played directly into the hands of capitalist forces and the elite of the country. There is therefore no doubt that in an emerging South Africa, neoliberal and capitalist policies being followed by the government has the potential of destroying the emergence of all education in the country.

\section{The Africanization of the Curriculum}

University ethos at South African universities must now after 21 years of so - called democracy must be influenced by an African Ethos. Universities as institutions should seriously think about establishing institutions that will be responsive to local African challenges. The manner, in which the mergers of South African universities were undertaken, does not augur well for this important scenario and necessity. Msila (2014: 43) states that "the time has arrived for Africans to reflect their stories, histories and languages in the higher education curricula." Nearly twenty one years after democracy, transformation has been most sluggish and is an indictment to the ANC led government. It is unfortunate to note that universities have been deliberately silent on, if not dismissive of, African curricula. Many institutions fail to see beyond the language debates, with some questioning the Anglicization of former Afrikaans universities or the introduction of African languages in former English Universities.

Msila (2014) states that "the serious challenge for an African University is to address the major obstacles in society, the first being a need to expand the pan - African ideal in Africa and the diaspora. It is obvious that in South Africa given the legacy of apartheid and historic colonialism, there is an urgent need to share cultural and historical awareness, and therefore, economic cooperation and the intellectual independence of all race groups must be recognized, for purposes of fostering much needed South African unity. Eurocentric paradigms are so indelible in higher education that African voices are needed to disprove the myth of the archaic nature of African thought that communities have internalized over decades and centuries of colonization. Second, there needs to be an intellectual revival. It is about reviving and embracing an African renaissance of the reality of being in Africa. Third, in a globalizing world, Africa's role 
needs to be magnified. African universities should reflect Africa's cultures, identities, languages, histories within their curricula." Currently, transformation efforts have tended to be marginal in higher education and it was not found expedient and necessary to factor this important issue into the merger debates and transformation processes.

It has to be openly realized by the government that the realization of African universities must be the culmination of the liberation struggle and the beginning of the construction of a really new South Africa. The absence of developing and building African Universities is a stunting of South Africa's growth. Government, its bureaucracy and South African University managements must now play a greater role in terms of consolidating efforts towards the Africanization of the curriculums, in order to position South Africa and Africa within the realm of African solutions for African problems, challenges within higher education.

\section{Some Challenges Facing Higher Education in South Africa}

Ramdass and Kruger (2014: 1) indicate that there must be a major emphasis on the education of the South African people to become responsible, participatory and reflective citizens that contribute to an emerging democracy. Higher education in South Africa is the factor that influences and determines the success of individuals, that has a national and international impact on the country and, therefore, higher education can contribute to the building of a united and democratic country. There are thus opportunities that present themselves twenty years into democracy that could improve the status of education in South Africa." In this regard and in an era of rapid change that is enforced through technological innovations, globalization, market expansion and mass production and access to higher education, the merger of South African universities lost sight of these variables in terms of the importance and organization of human capital. Thus any change that the merger processes envisaged in terms of redressing the imbalances of the past, did not factor into the equation the intellectual abilities of the majority, their fears, cultural backgrounds and to add to changing societal needs. In other words the merger exercises failed to understand and appreciate common goals for a country in transition from apartheid education to democracy. Against this scenario of change, the South African education system post 1994 still faces more than major challenges, with political instability that dominates education discourse after twenty one years of freedom and democracy. This is seen in terms of the tension between implementing higher education changes that need both time and considerable resources and the close relationship of issues that need to be addressed at the sites of implementation, in terms of schools, universities, and in the lives of human personnel.

The challenge is to improve the quality of education across the entire value chain and in this regard society and government including all educational authorities must instill morals, values, ethical conduct, honesty, integrity in terms of positive characteristics that were not factored into the merger processes. There seems to be a gap according to Ramdass and Kruger (2014: 12) "between secondary and higher education in addressing these issues and therefore as matters now stand new professionals cannot really contribute in positive ways and this impacts negatively on the economy and affects international relations. This is exemplified by the mergers of universities and technikons which have caused and created major problems in higher education. This has affected the entire teaching and learning process and service delivery in many organizations. The mergers according to Ramdass and Kruger (2014: 15) state that:

- "Universities have implemented their processes without due cognisance of a shortage of lecturers at both technikons and universities.

- Because the mergers brought about large universities, it has become most difficult to implement and control the communication processes.

- That, consideration was not given to the all embracing reality that universities do not and cannot exist in isolation.

- The merger exercises paid scant reference to the most important stakeholders in the form of industry, the role of government and of civil society.

- Consideration of the close collaboration between all stakeholders through a virtuous spiral of a sense of shared purpose was totally ignored. And thus the dialogue between the state, industry and universities has been very patchy and uneven which has characterized a weak understanding of these important variables."

Given the nature of the mergers salary levels of academics have not kept pace with other sectors and exacerbated even further by poor working conditions within higher education. All of this amongst other factors has resulted in the migration of academics to the private sector and often overseas, much to the peril of universities and this has contributed to the fall of academic standards and quality. Academia therefore needs to reclaim this lost ground in order to retain the much needed talent. In this regard leadership within all sectors needs to understand that academics are the pillars of economic and social development. 
Mergers have caused fear and uncertainty among staff and this has demoralized many and therefore, the higher education system must invest in the improvement of morale. Ramdass and Kruger (2014: 20) state that that universities need to develop a plan in order to develop a new generation of academics as the country is suffering a brain drain and skill shortages and doctoral graduates are too few.

\section{Conclusions}

- Mergers have to be reassessed and the challenges have to be rectified rapidly.

- Research output has to be increased in terms of the issues that confront the country.

- Top management and vice - chancellors have to be appointed on experience and merit and not on the basis of any racial engineering.

- The role of technikons as universities must be revisited such that they serve the vocational requirements of the country.

- The dilemma of the funding formula at universities used to calculate government subsidies for institutions of higher learning must be reevaluated.

- Political interference has to be curbed drastically.

- A host of other conclusions that can be drawn from the discussion undertaken in this paper, because the conclusions cited are not all inclusive.

\section{Recommendations}

- The entire merger process and its practicality must be overhauled and streamlined to serve the nation and students particularly from disadvantaged backgrounds.

- Serious consideration must be given to downsize some of the merged universities because of large distances.

- Consideration of allowing greater autonomy to some universities that were amalgamated thus allowing them to become more responsive to their immediate and past environments.

- Quality of education must become a fundamental requirement.

- Universities have to pay attention to creating a competitive workforce.

- More research needs to be undertaken to determine the success and failures inherent in the merger of universities and of government initiatives and their effects on the people, the economy and the country as a whole.

- Serious consideration to performance management must become an imperative.

- Affirmative action policies in respect of the appointment of academics must be reassessed.

- A host of other recommendations could be drawn from the discussion undertaken in this paper.

\section{Conclusion}

This paper attempted to situate the subject matter of the failed South African universities merger process and system in a democratic South Africa. In so doing the paper further discussed areas of possible intervention and reassessment of the merger process and their negative impact upon higher education. It is obvious that the South African government formulated a programme of restructuring the higher education system on principles of equity, human rights, democracy and sustainable development. In the main these have not been met in relationship to higher education transformation because of political interference and that the strategies that encompassed the merger initiatives were not well thought of and engineered to address redress and the challenges that higher education faces in the country. In other words the merger exercise has contributed to further inequality across the value chain and that human resources have been seriously compromised. South Africa faces a number of formidable challenges in the years ahead particularly in the realm of higher education. This paper therefore, provided an overview of the challenges that confront universities post the merger of universities and therefore, counteractive plans should be implemented to address the manifest problems caused by an inadequate merger process. Cognisance has been taken that these counteractive plans cannot be achieved overnight, but it calls for urgency to address and reengineer the higher education system some 21 years after democracy. In so doing the privileged status accorded to certain historically advantaged white former apartheid universities has to be reassessed in order that they serve the interests of the goals of broader transformation goals. The journey of once again reengineering the failed merger process must be borne out of necessity for purposes of access and growth of a failing economy and the failure of government in twenty one years to deal with the scourges of poverty, 
inequality and unemployment. In this regard it is essential that business and the private sector play a more meaningful role in the reconstruction of South African higher education. On the other hand government must now support private higher education institutions that have been accredited and registered by the Department of higher education and the CHE. All of this is important from the aspect of creating relationships among a diversified nation in order to usher in an era of prosperity through the higher education system.

\section{References}

Anis Mahomed Karodia; Dhiru Soni. (2013). The Inextricable Relationship between the Apartheid State and Public Sector Chaos in South Africa. International Journal of Development Research and Quantitative Techniques. 3 (2): Autumn. Pages 22 - 33.

Bailey, M. (2015). South Africa learn to love your teachers. Mail and Guardian. Johannesburg. South Africa. Page 39.

Dibetle Monako (2008). Untangling the merger mess. Mail and Guardian. Johannesburg. South Africa. 16 September. Pages $1-4$.

Hay, M; Karodia, A. M; Bayat, S; and Soni, D. (2013). The Persistent Question of Access in South African Higher Education: Need to Traverse New Virtual Terrains. International Journal of Mainstream Social Sciences. 3 (2) autumn. Brown Walker Press. United States pf America.

Hunter, Q; Mataboge, M; and Gqirana, T. (2015). We messed up says ANC. Politics. Mail and Guardian. Johannesburg. South Africa. February 6 to 12. Page 2.

John Higgins (2014). Academic Freedom in a Democratic South Africa: Essays and Interviews on Higher Education and the Humanities. Wits University Press. Johannesburg. South Africa. Book consulted by the authors.

John, V. Vast varsity pay gap exposed. Mail and Guardian. Education. Johannesburg. South Africa. January 23 to 29 . Page 14.

Karodia, A. M; Soni, D; and Rahman, S. (2013). The Inextricable Relationship between the Apartheid State and Public Sector Chaos in South Africa. International Journal of Development Research and Quantitative Techniques, 3 (2) autumn. Brown Walker Press. United States of America.

Kem Ramdass; and David Kruger (2014). The challenges facing higher education in South Africa. A position paper. University of Johannesburg. Republic of South Africa. August. Unpublished Manuscript. Pages 1 - 33.

Kilfoil, W. R; Groenewald, T; (2005). Mergers and Change Management at the Micro Level: A Case Study. Journal of Human Resource Management. 3 (2). Page 11 to 18. Paper consulted as background reading and not quoted in text.

Laura Grant (2015). The walk falls short of the talk. Mail and Guardian. Johannesburg. South Africa. Page 8.

Leisi Loouw - Vaudran (2014). War on schoolchildren escalates. Mail and Guardian. Johannesburg. South Africa. November 14 to 20. Page 29.

Mercury (2015). 90000 students apply for admission to the University of KwaZulu Natal after the release of the matriculation results. Provincial Newspaper. Durban. South Africa. Page 2.

Michael Chapman (2014). Enlightened leadership needed to secure academic freedom. Mail and Guardian. Johannesburg. South Africa. October 10 to 16. Page 38.

Michael Cherry (2014). Sorry Tale of a post - merger mess. Mail and Guardian. Johannesburg. South Africa. December 5 to 11. Page 39.

Nithaya Chetty; and Christopher Merrett (2014). The Struggle for the Soul of a South African University: The University of KwaZulu Natal Academic Freedom, Corporatization and Transformation. UKZN Press. South Africa. The book was consulted in order to crystallize the authors thought processes.

Nithaya Chetty; and Christopher Merrett (2014). UKZN's crucible of poor decisions. Mail and Guardian. Johannesburg. South Africa. September 26 to October 3. Page 45. Sean Muller (2014). Transformation is not UCT's priority. Mail and Guardian. Johannesburg. South Africa. November 21 to 27 . Page 42.

Nkosi, B. (2015). When Learning's door get bolted. Mail and Guardian. Johannesburg. South Africa. February 20 to 26 . Page 11.

Robert Renwick (2015). Mandela's master plan to forge ties with Iron Lady. Sunday Times. Johannesburg. South Africa. Page 15.

Robert Sedgwick (2004). Institutions of Higher Education in South Africa after the Mergers. Archive material WENR. Pretoria. South Africa. 1May. Pages $1-3$.

Salim Vally; and Enver Motala (2014). (Editors). Education, Economy and Society. Unisa Press, Pretoria. South Africa. Book consulted by the writers of this article.

SASCO (2009). Beyond the Big Bang Mergers: A Critical Review of the Higher Education Mergers in South Africa. $16^{\text {th }}$ National Congress Discussion Document: Education Transformation. Johannesburg. South Africa. Pages 1 - 12.

Soni, D; Karodia, A. M; and Dwakinun. D. (2013). Basic Education or School Going Education for South Africa: Privatization versus the Public Good. International Journal of Cross - Cultural Studies. 3 (2) autumn. Brown Walker Press. United States of America.

Steven, J. Klees. (2014). Neoliberal policies destroy human potential and devastate Education: A Review of the book by Salim Vally and Enver Motala - Education, Economy and Society (Editors). Mail and Guardian. Johannesburg. South Africa. July 18 to 24. Pages 36 and 37

Van Rheede, C. (2015). Politics is steering SA to disaster. Afrikaanse Handelsinstituut's CEO. Sunday times. Johannesburg, South Africa. Page $2-3$.

Veriava, F. (2015). Public participation under threat (Education). Mail and Guardian. Johannesburg. South Africa. January 23 to 29. Page 38.

Vuyisile Msila (2014). Africa must take pride of place. Mail and Guardian. Johannesburg. South Africa. November 14 to 20. Page 43.

Weber, E. Ed. (2008). Educational Change in South Africa: Reflections on Local Realities, Practices and Reforms. Sense Publishers. Rotterdam. Netherlands.

William Gumede (2014). Time to end academia's ivory trade. Mail and Guardian. Johannesburg. South Africa. August 15 to 21. Page 42. 